\title{
LEGISLATIVE THEORY AND THE RULE OF LAW: SOME COMMENTS ON RUBIN
}

\author{
Peter L. Strauss*
}

Professor Rubin's article is an admirable piece of work on many levels, from its attention to jurisprudence to its concern with the practical changes in the Congress and its function, and their implications. In commenting on it, I mean to restrict myself to the latter subjects. These are the matters that have the closest tangency to my own work and produce for me the strongest response. Professor Rubin has given us a compelling statement of the problems posed for contemporary constitutional and legislative theory by one transformation in statutory practice accompanying the rise of the administrative state, the change from direct ("transitive") legislative resolution of policy problems to indirect ("intransitive") resolution through the empowerment of agents who are to determine policy problems under instruction. These changes, he argues, undercut such conventional doctrinal norms as "delegation" and "void-for-vagueness" as means for assessing legislative action.

One encounters the changes Professor Rubin describes on every hand. They are almost certainly irreversible, given the increasingly complex and interdependent ways in which we understand our existence. As a description of changes and as an assessment of the corresponding inadequacies of our existing models and theories about legislation, his essay is compelling. What a commentary might hope to do is to suggest a series of next steps in the analysis, further questions that might be asked as we seek to develop the new body of legislative theory for which he calls.

For this reader, at least, not all of Professor Rubin's suggestions about future directions are equally as compelling as his assessment of the current situation. This is in part because of the need to develop a sharper picture than he gives us of just who the actors really are that count in a world of intransitive legislation-not just elected politicians, but increasingly a body of staff who have substantial room to act on their own initiative. And it is in part because of a failure to see that once the conversion has been made from "transitive" to "intransitive" statute-making, the theoretical question requires looking more broadly at government-as-a-whole. It becomes then a question about controland that question is not only one about Congress's relation to the agencies (the question on which he would have us focus), but also about the

* Betts Professor of Law, Columbia Law School.

Among the usual debts to colleagues, friends and faculty workshops (at Columbia and Cornell), a few stand out: Alex Aleinikoff, Bernard Black, Ricky Revesz, Andy Rutten and Roy Schotland. Welcome financial support for this and a related enterprise came from the Abraham N. Buchman Fund for Administrative Law. 
people's relationship to both Congress and the agencies; and also about our relationship to the President, and the President's relationship to the agencies. This is, if you like, the separation-of-powers question; one needs to account for the President and the courts as well as the Congress, and for the impact of change in Congress on how we would wish Congress (and our government generally) to be. ${ }^{1}$

It may be useful to begin with a concrete example of the change to which Professor Rubin calls our attention. His examples, understandably enough in terms of his own career, are drawn from banking regulation; perhaps a more fully developed example from another area of law will illustrate the principal observation on which his paper is based. The example will also develop background for later development of questions about the completeness of his analysis and suggestions for its further development.

Railroads constituted a major source of social cost in late 19th century America, as well as a major element in the economy. ${ }^{2}$ The failure of the railroads to purchase effective and available safety technology for their locomotives and freight cars and to implement standards of compatibility among them had contributed substantially to a staggeringly hazardous industrial setting: over twenty thousand workers were being injured annually, and over two thousand killed, in accidents that were largely avoidable. The common law contributed little impetus to changing these results; "assumption of the risk," "contributory negligence" and the "fellow servant" doctrine impeded workers' lawsuits. Even in the absence of these elements a railroad would not be found to have been negligent for providing equipment less safe than it might be, if it had provided its workers with the equipment in common use at the time. The hazards of the workplace, as it ordinarily was, provided the ground against which possible common-law liability was to be assessed.

Congress enacted the Federal Railway Safety Appliances Act of

1.

In this century, the nexus of policy making has largely shifted from the constitutionally designated branches of government to the bureaucracy: the system of shared powers created by the Constitution has become a system of shared influence over bureaucratic decision making. Each branch of government possesses many tools with which to influence the bureaucracy; both Congress and the president attempt to design institutional arrangements to effectively oversee and control bureaucratic decision making. These institutional arrangements channel and constrain policy making within the bureaucracy.

Congress: Structure and Policy 403 (M. McCubbins \& T. Sullivan eds. 1987).

2. The two paragraphs following draw on materials concerning the development and implementation of the Federal Railway Safety Appliances Act of 1893, 27 Stat. 531 (codified as amended at 45 U.S.C. $\$ \S 1-43$ (1982)), collected in P. Strauss, Materials for a Course in Legal Methods 106-248 (prov. ed. 1988). See, in particular, Kohn v. McNulta, 147 U.S. 238 (1893); H. Rep. No. 1678, 52d Cong., 1st Sess. (1892); 24 Cong. Rec. 1246-51, 1273-88, 1323-33, 1370-76, 1416-18 (1893); L. Friedman, A History of American Law 482-84 (2d ed. 1985). 
$1893^{3}$ with the avowed purpose of forcing use of the new and safer technologies. Although, atypically for its time, the statute delegated limited functions to an administrative agency (the Interstate Commerce Commission), it was predominantly "transitive" in character. It told the railroads just what technologies they were to employ (power brakes, automatic couplers, "grab bars," and coupling equipment whose height would not vary from standard whether the cars were loaded or empty), and declared the sanctions that were to apply in the event of failure. While the ICC was permitted to make certain interim decisionswhether to postpone the effective date of a standard, whether to recommend a prosecution to the Attorney General-Congress generally placed enforcement power in the hands of the prosecutors and the courts. With a trivial exception, ${ }^{4}$ no standard remained to be developed at a later time or by another authority. One reading the congressional debates is immediately gripped by a sense, not only of their seriousness of purpose and genuineness as debates, but also of their sharp focus on precise definition of the appropriate legal response to the problem at hand. That was Congress's business.

By 1966, the automobile had displaced the railroad as mainstay of the economy and major source of personal injury. Over fifty thousand Americans were dying annually in automobile accidents, with enormous additional losses in bodily injury and property damage. ${ }^{5}$ It was coming to be widely believed that a substantial proportion of this carnage could be avoided if only the automobile were as well equipped for safety in collisions as it was for stylish appearance. Some suitable technologies, like the seat belt, were available; others, it was confidently thought, could quickly and easily be designed. Few consumers were ordering such optional safety technologies as were available, and the automobile manufacturers were expending little effort to develop new ones. Again, the common law provided little in the way of incentive; in the fifty years since the decision in MacPherson v. Buick Motor Co. ${ }^{6}$ automobile manufacturers had come to accept that they would be held to produce cars that were free of defects and reasonably fit for their intended use as

3. 27 Stat. 531 (codified as amended at 45 U.S.C. $\S 11-43$ (1982)).

4. The American Railway Association was given 90 days to reach an agreement among its members setting the uniform height of the drawbars, and the Commission was instructed to set the height if it failed to do so. Id. $\S 5$ (current version at 45 U.S.C. $\S 5$ (1982)).

5. The two paragraphs following also draw on Strauss, supra note 2, at 503-727, which discusses the development and implementation of the National Traffic and Motor Vehicle Safety Act of 1966, Pub. L. No. 89-563, 80 Stat. 718 (codified as amended at 15 U.S.C. $\$ \S 1381-1431$ (1982 \& Supp. IV 1986)). The interested reader should watch for publication of J. Mashaw \& D. Harfst, The Freedom Machine (forthcoming by Harvard University Press), which tells the story of this legislation, in Congress and out, in its rather unpleasant detail; a version has appeared as Mashaw \& Harfst, Regulation and Legal Culture: The Case of Motor Vehicle Safety, 4 Yale J. on Reg. 257 (1987).

6. 217 N.Y. 382,111 N.E. 1051 (1916). 
automobiles; but they were not held to foresee that their products would be involved in collisions, and thus the law was indifferent to their failures to design their products for safe performance in the event of an accident. ${ }^{7}$

The National Traffic and Motor Vehicle Safety Act of $1966,{ }^{8}$ like the Railway Safety Appliances Act of 1893, sought to force the development and deployment of safety technology. Congress was not prepared to decide, however, what measures should be taken to render cars acceptably safe. It gave authority to an agency within the Department of Commerce (soon to be transferred to the Department of Transportation) to decide, following rather elaborately stated procedures, what safety standards would be "reasonable, practicable and appropriate for the particular type of motor vehicle . . . for which it is prescribed," would "meet the need for motor vehicle safety" and could "be stated in objective terms.",9

The contrast with the "transitive" Safety Appliances Act is striking. The 1966 Congress, in the same legislative breath, decided far less for itself and required its agency delegate to exercise much more detailed choice and supervision over the automobile industry than the 1893 Congress had done concerning the railroads. And one reading the legislative history finds similar contrasts. The 1966 legislative process differed profoundly from that of 1893 , both for institutional reasons and in view of the changed nature of the legislative product. Used to leaving matters to its own growing bureaucracy and that of executive government, and consumed with the demands of overseeing both, the 1966 Congress had neither time nor inclination to attend to legislative detail; there was no debate worthy of the name, just rhetoric about the seriousness of the problem and the need, at last, to see that something was done about it. This is, then, an excellent example of an "intransitive" statute.

\section{Congressional Size as an Added Element of the Description}

Our understanding of the change would be considerably enriched, and our perspective perhaps shifted, if we were to look as hard at changes in Congress the institution as at changes in its work-product. Professor Rubin indeed notes that the changes in legislative work-

7.

The intended purpose of an automobile does not include its participation in collisions with other objects, despite the manufacturer's ability to foresee the possibility .... [T] he defendant also knows that its automobiles may be driven into bodies of water, but it is not suggested that defendant has a duty to equip them with pontoons.

Evans v. General Motors Corp., 359 F.2d 822, 825 (7th Cir. 1966).

8. Pub. L. No. 89-563, 80 Stat. 718 (codified as amended at 15 U.S.C. $\S \S 1381-1431$ (1982 \& Supp. IV 1986)).

9. 15 U.S.C. $\S 1392(\mathrm{f})(3), 1391(2), 1392(\mathrm{a})$. 
product-intransitive rather than transitive statutes-may be owing not only to changes in the nature of the problems having to be solved (their added complexity and the like), but also to changes in the institution producing them, Congress itself. ${ }^{10}$ Yet he does not ask whether the latter changes give rise to difficulties of their own. He describes as "reforms" such alterations as "the increase in professional staff, the modification of the seniority system and the creation of congressional agencies such as the Congressional Budget Office." 11 In my judgment, the "reform" characterization is not obvious; we need fuller analysis of these changes before reaching prescriptive conclusions. Considering political controls exercised by Congress as part of a new theory of intransitive legislation will require us to consider who will be exercising those controls, in what circumstances, subject themselves to what oversight, and with what if any necessary connection to the views (various as they will be in the usual situation) that underlay the legislation as a whole.

One of the differences between the Congress of the transitive late19th century and the Congress of the intransitive present is the simple fact of size. The Congress of that era had little in the way of professional staff; 12 its members dealt with one another, and one may imagine that that had a good deal to do with the transitivity of its output. The debates over the Safety Appliances Act were debates among individuals who had themselves studied the problem and come to conclusions, and who were, transparently, reasoning with one another about the precise shape of a desirable outcome. The Congress of today is a bureaucracy of over twenty thousand ${ }^{13}$-many in agencies such as the Congressional Budget Office or the General Accounting Office of Bowsher $v$. Synar ${ }^{14}$ fame, but thousands also in the offices of individual members or on the staffs of congressional committees. The change reflects a dramatic alteration in the nature and possibilities of legislative function. While "[h]aving a substantial number of staff people with appropriate investigative authority seems a necessary condition for congressional oversight of the executive branch and the independent regulatory commissions," writes M. Malbin, "there is a gloomier side: the effect of staffs on Congress's ability to act as a deliberative body." 15 Use of staff marginalizes debate and discussion among elected representatives and

10. Rubin, Law and Legislation in the Administrative State, 89 Colum. L. Rev. 369, 396 (1989).

11. Id.

12. Polsby, The Institutionalization of the U.S. House of Representatives, 62 Am. Pol. Sci. Rev. 144, 158-60 (1968), reprinted in Congress: Structure and Policy, supra note 1 , at 91 .

13. See infra note 16 .

14. 478 U.S. 714 (1986).

15. M. Malbin, Unelected Representatives: Congressional Staff and the Future of Representative Government 240 (1980). 
introduces serious problems in information management and assessment. Nor has the use of staff

left the members with more time to concentrate on their legislative work. . . . [W] hile representatives as recently as 1965 spent almost one full day every week on legislative research and reading, by 1977 the time spent on reading was down to an average of eleven minutes per day. In other words, instead of freeing the members to concentrate, the staffs contribute to the frenetic pace of congressional life that pulls members in different directions, reduces the time available for joint deliberation, and makes concentration all but impossible. ... The situation feeds on itself. The members need staff because they have so little time to concentrate, but the new work created by the staff takes even more of the members' time, indirectly elevating the power of Washington issue networks in which the staffs play so prominent a role. ${ }^{16}$

One must immediately concede that "the curse of bigness" is hardly a problem for the Congress alone, ${ }^{17}$ and that it may be hard to pin down propositions about cause and effect. Consider the following possible accounts, which need not be taken as mutually exclusive. The first is that the growth is the result of technological developments-as simple as the availability of the jet plane and the evening television news, and what they connote for congressional behavior: more frequent trips home; more visitors at the office; more emphasis on expo-

16. Id. at 242-44. A more recent assessment is no different:

In 1974 , there were 16,000 people on House and Senate staffs at a cost of $\$ 328$ million. Today, there are 20,000 at a cost of a shade less than $\$ 1$ billion. . . Why has Congress grown so much? Not because this is a bigger country. Since 1970 , the population has increased by 7 percent; Congressional staffs have increased 43 percent. Not because the issues are more complex; they have always been complex.

The fundamental reasons are the members' desire to make a mark, to get publicity and the need to raise campaign funds.

M. Gwirtzman, Far Too Many People on Capitol Hill, N.Y. Times, May 14, 1988, at A31, col. 3. Mr. Gwirtzman notes that at last count there were more than 250 separate subcommittees-12 on the subject of international economics alone-and that "the present average of 60 various hearings a day means some members are scheduled into three or four at once, in addition to their other work." Id.

17. Respecting the Executive Branch see, e.g., H. Merry, Five-Branch Government: The Full Measure of Constitutional Checks and Balances (1980); D. Price, America's Unwritten Constitution: Science, Religion, and Political Responsibility (1983); B. Patterson, The Ring of Power: The White House Staff and its Expanding Role in Government (1988). Respecting the judiciary, see, e.g., R. Posner, The Federal Courts: Crisis and Reform (1985); Strauss, One Hundred Fifty Cases Per Year: Some Implications of the Supreme Court's Limited Resources for Judicial Review of Agency Action, 87 Colum. L. Rev. 1093 (1987). In addition, a Conference on the Presidency and the Press, at Columbia University School of Law (Jan. 18, 1989), heard Hugh Sidey of Time Magazine ascribe much (unfavorable) change in the character of White House-press relations to the growth of the White House press corps from a knowable few dozen to a wolf-pack of 1400 . 
sure to voters and personal celebrity rather than old-fashioned party politics as the basis for a career. The second and related account, given by public choice theorists, is that the behavior of members of Congress is fundamentally to be understood in terms of the drive for reelectionreelection to be secured by increasing personal opportunities for credit-taking (general, intransitive legislation of the do-somethingabout-this-problem type, or private casework for constituents) and avoiding public resolution of difficult issues (transitive legislation). Third (a competing political science vision), one could argue that state actors wield (and hence seek to enlarge) power quite independent of the electorate, an activity more likely to be successful if they have a loyal apparatus to assist and if there exist opportunities for private, personal action than if they must act in a setting requiring public collaboration with others; ${ }^{18}$ thus, the internal congressional reforms of the early 1970 s-the replacement of powerful committee chairmen operating under seniority rules with much more dispersed authority structures-added to the need for staff and provided many more opportunities for the exercise of essentially private power. A fourth, and related, account would be that Congress's incentives and need for staff have been influenced, if not distorted, by two decades, almost uninterrupted, of Republican Presidents and Democratic Congresses; the truly massive growth in congressional staff of the early 1970s occurred at the time of the budget and impoundment struggles between the Republican (Nixon) White House and Democratic Congress, which resulted in creation of the Congressional Budget Office and a massive supplementary congressional budget operation.

Whichever of these explanations we choose to accept, or perhaps others that could be imagined, we are left with the fact of a swollen staff apparatus and, accordingly, significant issues of control. In effect, congressional process has itself become intransitive-members put more effort into control and less into specification-and it has also become fragmented and depersonalized. These changes, too, need to be considered in moving from a description of the need for a new theory to an effort at formulation. They provide, if you like, possible reasons for an "attitude of distrust about the modern legislative process" 19 that are quite contemporary and not at all linked to sentimental attachments to the old. While it has always been hazardous to speak anthropomorphically of a legislature, as if it were a unified body capable of memory and intention, those difficulties are compounded when personnel proliferate, responsibilities are spread, and concerted action is abandoned in favor of individualized or even committee oversight. "The hazard is that a body like Congress, when it gets into detail, ceases to be itself; it

18. E. Nordlinger, On the Autonomy of the Democratic State (1981).

19. Rubin, supra note 10 , at 387 . 
acts through a fraction which may be a faction.",20

Indeed, the enlargement of congressional staff could be seen as contributing to the specificity of legislation, albeit a specificity that may heighten factional dangers, as Congress struggles with the President for political control of government. It has been frequently enough remarked that the statutes of the health and safety regulatory outpouring of the 1960s and early 1970s were quite a bit more, not less, specific than the economic regulatory statutes of the 1930s. Thus the 1977 amendments of the Clean Air and Clean Water Acts, reacting to apparent failures of administrative (executive) action, indicated in some detail the pollutants to be regulated and the deadlines to be met in doing so. ${ }^{21}$ The 1986 amendments to the Safe Drinking Water Act refer to a table of contaminants the agency had published in the Federal Register as part of an advanced notice of proposed rulemaking, requiring the agency to act on those contaminants within stated times and permitting only limited substitutions. ${ }^{22}$ After skimming the public laws enacted by the first session of the 100th Congress-not a recommended activity-I can report that virtually all laws enacted by that Congress were intransitive in Professor Rubin's sense; they assigned chores to one or another Secretary or Commission. Yet scattered through their pages were provisions of striking specificity. Section 202(e) of the Water Quality Act of 1987, a statute running 84 pages in Statutes at Large, provides that " $[t]$ he activated bio-filter feature of the project for treatment works of the city of Little Falls, Minnesota, shall be deemed to be an innovative wastewater process and technique for purposes of " federal grant support. ${ }^{23}$ Without that provision, whether to qualify the bio-filter feature would have been a matter for administrative detail. Similarly, the twenty-three page National Appliance Energy Conservation Act of 1987 sets maximum permissible energy consumption levels for a variety of household appliances; ${ }^{24}$ and the 130-page Surface Transportation and Uniform Relocation Assistance Act of 1987 specifies the rush hour restrictions for a suburban Washington, D.C. highway. ${ }^{25}$ Perhaps especially striking in its implications for the contemporary uses of congressional staff is section 415(a) of the Competitive Equality Banking Act of 1987, which provides that the Senate and House Banking Committees are each to "monitor and review" the informal review proceedings of the Federal Home Loan Bank Board when bank examiners'

20. Macmahon, Congressional Oversight of Administration: The Power of the Purse (pt. 2), 58 Pol. Sci. Q. 380, 414 (1943).

21. See the Clean Air Act, 42 U.S.C. $\S \S 7409$ (c), 7411 (f)(1) (1982) (specifying timetables and pollutant); the Clean Water Act, 33 U.S.C. $\$ 1311$ (b)(2)(c) (1982) (specifying pollutants and time for action).

22. 42 U.S.C. $\S 300 \mathrm{~g}-1$ (b)(1)-(2) (Supp. IV 1986).

23. Pub. L. No. 100-4, § 202(e), 101 Stat. 7,16 (to be codified at 33 U.S.C. $\S 1282$ ).

24. Pub. L. No. 100-12, §325(a)-(i), 101 Stat. 103, 108-13 (to be codified at 42 U.S.C. $\$ 6295)$.

25. Pub. L. No. 100-17, § 147, 101 Stat. 132, 180-81. 
decisions about appraising or classifying savings bank loans are called into question there. ${ }^{26}$

If this is a return toward transitivity, it is a return in a special sense, made possible only by the enormous growth in congressional staff and armed by politics. One need not see this as irresponsible; the staff have bosses, and it is in their interest to find out what will satisfy those bosses and then to bring about that state of affairs. ${ }^{27}$ Yet it is also hard to pretend that such matters reflect judgments of any members of Congress outside the responsible committee (or, perhaps, even the judgments of most within it), and the committee presents the factional dangers already described. As between a judgment by that faction, loosely responsible to the Congress as a whole, and an agency head loosely responsible to the President, a contemporary theory of public law free of the problems introduced by Republican presidencies and Democratic legislatures might well prefer the latter. Whether the use of staff is producing more low-level monitoring or quixotically precise statutes, or both, the implications of its presence and behavior require us to know a good deal more about the institution before we can decide just what we want to do about it. ${ }^{28}$

To take one concrete example of a possible outcome of such analyses, consider the recent reawakening of respectability for arguments that statutes ought to be interpreted on the basis of what they say, not what their legislative history might appear to reveal. Over the years, lawyerly and judicial debate about how best to interpret statutes has been a compound of several elements-suspicion about what populist legislation might do to the formal unity of the common law; concern to suppress judicial subjectivity; doubt about the existence of shared congressional "intentions" on issues of meaning or, in any event, about the possibility of accurately reconstructing them; the conviction that statutes in a democracy should be taken as a source of law superior to the common law; the belief that attention to legislative history would, as an exercise, tend to take judges outside themselves and closer to the popular will that statutes reflect. If, for a while following the New Deal, these debates were moving toward closer consideration of legislative materials - to the point even of excluding judges from a tradition of being responsible as the general systematizers of law ${ }^{29}$ - the recent sig-

26. Pub. L. No. 100-86, § 415(a), 101 Stat. 552, 622 (codified at 12 U.S.C.A. $§ 1437$ (West Supp. 1988)).

27. Suppositions about the general effectiveness of such controls are at the root of analyses such as Calvert, McCubbins \& Weingast, A Theory of Political Control and Agency Discretion (1987) (on file at Columbia Law Review).

28. See Devins, Appropriations Redux: A Critical Look at the Fiscal Year 1988 Continuing Resolution, 1988 Duke L.J. 389.

29. I take this to be the general point of the Supreme Court's 5-4 decision in United States v. American Trucking Ass'ns, 310 U.S. 534 (1940). The case has been understood for generations as a watershed in statutory interpretation, but simplistically described as marking the divide between unthinking "plain meaning" interpretation and 
nals are that recognition of the changes in congressional process are moving the courts in very different directions. ${ }^{30}$

Members of Congress, their staffs, and those who try to influence them appear to have noticed that congressional reports have their uses, not only within Congress, but also after Congress has finished its work. It is commonplace that seeing that congressional reports are influential upon later events-especially so for intransitive statutes-politicians wishing to shape those later events turn their attention to shaping the congressional reports. Any reader of contemporary committee reports must be struck by the frequency with which remarks such as "the Committee intends" are to be found. ${ }^{31}$ And any realistic reader understands that these remarks are ordinarily written by staff, often at the behest of lobbyists, not by the members of Congress themselves. Moreover, as prior discussion suggests, the proposition that reports are read, rather than prepared for their possible impact upon later events, is increasingly an amiable fiction-at least if the reader is supposed to be the harried Senator, the person who actually casts a vote. The Senator has time only for a hasty conversation with an aide, who has no time to explain details.

Does it then make sense to rely upon reports as significant indicators of the meaning of the legislation to which they refer? National Small Shipments Traffic Conference, Inc. v. Civil Aeronautics Board ${ }^{32}$ is an

interpretation willing to attend the signals of congressional understanding to be found in the legislative history. One seeing that the majority had among them barely ten years of experience on the Court, and that the minority included in their number Chief Justice Hughes and Justice Stone, might think that the decisive proposition had more to do with the distinctive issues of the New Deal. Stone, in particular, was-for his time-among the strongest proponents of thoughtful statutory interpretation and the superior claim of Congress, but he married that position to an understanding that the judge's role was that of melding statute and case law into a unified whole. Stone, The Common Law in the United States, 50 Harv. L. Rev. 4, 12-16 (1936). It is that strong judicial role that the New Deal characteristically distrusted and the American Trucking majority rejected, in favor of a view that treated statutes as referenced to historical congressional understandings alone.

It is not hard to find in recent discussions of statutory interpretation-for example, in Aleinikoff's contrast between "archaeological" and "nautical" styles of interpretation, Aleinikoff, Updating Statutory Interpretation, 87 Mich. L. Rev. 20, 21 (1988)-a reawakening of that debate.

30. Perhaps the Republican-Democratic division between the White House and Capitol Hill also plays a role here. While the Reagan administration was enthusiastic for "original intent" in the constitutional context, one's impression is that its judges, Republicans, have been leading the charge away from reliance on legislative historythat is to say, Democratic history. See, e.g., Easterbrook, Statutes' Domains, 50 U. Chi. L. Rev. 533, 544-52 (1983); United States v. Ron Pair Enterprises, Inc., 109 S. Ct. 1026 (1989); Starr, Observations About the Use of Legislative History, 1987 Duke L.J. 371, 377, 379; K Mart Corp. v. Cartier, Inc., 108 S. Ct. 1811 (1988) (opinions of Kennedy and Scalia, J.J.).

31. E.g., S. Rep. No. 1301, 89th Cong., 2d Sess. 6-7, 9, 13-15, reprinted in 1966 U.S. Code Cong. \& Admin. News 2709, 2714-15, 2717, 2720-23.

32. 618 F.2d 819, 827-28, 831-32 (D.C. Cir. 1980). 
early example of a modern court troubled by this issue. The case involved the question whether a recently enacted statute permitted the Civil Aeronautics Board (CAB) to exempt air cargo carriers from certain regulatory requirements. Statutory language strongly suggested that it did. The only explanation of that language appeared in a conference report, which said that "the Managers [of the conference report] do not contemplate that the Board will exempt carriers from the requirement ...." ${ }^{33}$ The D.C. Circuit put this legislative history aside in the face of statutory language that it thought clearly authorized the CAB's action. Its refusal to rely on the conference report struck a broader note of skepticism about the uses and abuses of legislative history. "Courts in the past," the court observed,

have been able to rely on legislative history for important insights into congressional intent. Without implying that this is no longer the case, we note that interest groups who fail to persuade a majority of the Congress to accept particular statutory language often are able to have inserted in the legislative history of the statute statements favorable to their position, in the hope that they can persuade a court to construe the statutory language in light of these statements. This development underscores the importance of following unambiguous statutory language absent clear contrary evidence of legislative intent. ${ }^{34}$

A different but equally important response to the problems produced by the size of the congressional enterprise as well as its intransitivity is found in the increasing willingness of the courts to acknowledge that statutory texts lack fully determinate meaning. Perhaps especially noteworthy is the following passage from Chevron U.S.A. v. Natural Resources Defense Council: 35

In these cases, the Administrator's interpretation represents a reasonable accommodation of manifestly competing interests and is entitled to deference: the regulatory scheme is technical and complex, the agency considered the matter in a detailed and reasoned fashion, and the decision involves reconciling conflicting policies. Congress intended to accommodate both interests, but did not do so itself on the level of specificity presented by these cases. Perhaps that body consciously desired the Administrator to strike the balance at this level, thinking that those with great expertise and charged with responsibility for administering the provision would be in a better position to do so; perhaps it simply did not consider the question at this level; and perhaps Congress was unable to forge a coalition on either side of the question, and those on

33. H.R. Conf. Rep. No. 773, 95th Cong., 1st Sess. 14-15, reprinted in 1977 U.S. Code Cong. \& Admin. News 3396, 3399-400.

34. National Small Shipments Traffic Conference, 618 F.2d at 828; accord TVA v. Hill, 437 U.S. 153, 172-73, 184-93 (1978); Hirschey v. FERC, 777 F.2d 1, 7-8 (D.C. Cir. 1985) (Scalia, J., concurring).

35. 467 U.S. 837 (1984). 
each side decided to take their chances with the scheme devised by the agency. ${ }^{36}$

The scenarios described (along with some others) are just those that explain much legislative intransitivity.

The proposition about "tak[ing] their chances with the scheme devised by the agency" ought to caution against any universal rejection of the worth of committee reports or other artifacts of legislative history in the world of the intransitive statute and the swollen staff. Legislative history speaks to the agency much more loudly than it does to the court, which does not have to undergo continuing relationships of oversight and budgetary dependency. A number of reasons may exist for encouraging (or at least accepting as inevitable) its use at the agency level. Courts have long recognized the "contemporaneous construction[s]" of statutes by those appointed to administer them as powerful indicators of statutory meaning. ${ }^{37}$ They have done so, in substantial part, because of the agency's fuller and more accurate political sense of the situation. Under intransitive statutes, for which the first reading of a statute typically will not be a court's, one might think it better that this political good sense be derived from signals sent in public-that is, from committee reports however written-than from signals more privately conveyed. ${ }^{38}$ The agency, if a participant in the drafting, may well have tools to distinguish false from valid signals of full congressional politics that a court would lack.

Any propositions about subsequent political controls by the legislature ought to give the most careful attention to the questions earlier raised. The farther one moves from enactment, the harder it is to pretend either that Congress held an (inexplicit) view that the agency could sense, or that the particular committee, member of Congress or staffer communicating with an agency represents that view. For while individual members responsible for oversight may have views on one or more of the issues left open, the body did not; and the disjunction will only get larger as the years go on and as oversight is exercised or structured by persons other than those entitled to vote on the floor.

One can make this point in a theoretical way connected with Professor Rubin's discussion of the principal/agent problem. He proceeds as if there were only one such problem-that between Congress and its agent, the agency. In fact, there are two principal/agent problems immediately at work, and others in the wings. Congress is also an agent of the citizens; it is neither our only agent, nor our only agent in what could be called a principal/agent relationship with the agencies. When Rubin remarks that "the legislature may be better able to control an

36. Id. at 865 (emphasis added) (footnotes omitted).

37. E.g., Norwegian Nitrogen Prods. Co. v. United States, 288 U.S. 294, 315 (1933).

38. One cannot doubt that, for the reasons Professor Rubin describes, the signals will be sent. See Rubin, supra note 10, at 394 . 
administrative agency than to control itself," 39 he ought more properly to say that Congress may be better able to control an administrative agency than we can control Congress, and that suggests some additional difficulties to which a new theory of legislation must respond. Indeed, putting the problem this way highlights both that Congress is not our (the citizens') only agent, and that it is our agent for limited purposes. That conclusion ought to underscore earlier observations about presidential-congressional competition and sharply raise separation-of-powers issues. We ought not be talking only about the Congress.

\section{The Proper Field of Description}

Professor Rubin's basic point might be restated as follows: our existing body of legislative theory, in assuming that legislatures will (and should) act transitively, focuses on issues of specification-has the legislature been sufficiently precise? Has it permitted others to reach conclusions that ought to be made only by it? Once we admit that a legislature may act intransitively - we can no longer hope to deny that it may-tests of specificity lose their point; the issue on which theory must now focus is that of control.

This analysis is persuasive. While I shall suggest later on that "delegation" and "void-for-vagueness" may have their continuing uses if viewed from a slightly different angle, the observation that they are premised in the idea of legislation as transitive in character is apt. Yet the proposition that we ought now to be generating a legislative theory premised on ideas of control might be thought to carry with it a change in analytic and normative perspective for which Professor Rubin does not account. Once control becomes the focal issue of theory, we notice that the legislature is not the only part of government controlling; the courts control and, within the more political realm, the President also controls. ${ }^{40}$ The growth of the administrative state has not been a function only of change in legislative function; as government has swelled and its tasks proliferated, executive arrangements and our expectations about them have changed as well; and so have the relations between agencies and courts.

Surely it is enough, the reader may respond, to attend to the changes on the legislative side. And for detailed attention, that may be conceded. Yet any legislative theory we may have is necessarily to be caught up in a more general theory of government-the more so given the totemic quality of separation-of-powers considerations in the Amer-

39. Id.

40. More properly, the Presidency controls. Here, as with the Congress, interactions are managed by a bureaucracy itself under imperfect control, not by the President himself. See, e.g., National Academy of Pub. Admin., Presidential Management of Rulemaking in Regulatory Agencies (Jan. 1987); B. Patterson, supra note 17. 
ican context. Granted the importance of controlling agencies that have been given important social responsibilities under intransitive statutory instructions, that proposition only opens the question to what extent that control should occur through the open, event-focused, and somewhat rationalistic techniques characteristic of the courts, and to what extent through political processes. And then, if one decides that some ongoing political controls are essential, as inevitably one would, the further question arises how they ought to be distributed between President and Congress. That question requires some attention to the problem whether different executive and legislative roles can profitably be imagined in an era when the top layers of government are characterized more by control than performance;" and to how particular "control" functions that might be envisioned for the legislature-say, the legislative veto-might affect its continuing performance of function, or its relation with the President. These questions Professor Rubin elides; yet they bear importantly on some aspects of his analysis.

To make the point concrete, consider the Supreme Court's recent decision in Morrison v. Olson, ${ }^{42}$ the Independent Counsel litigation. The case concerned a challenge, on separation-of-powers grounds, to an "intransitive" statute enabling the appointment of prosecuting officials more than usually independent of presidential direction. These officers and such executive branch control processes over them as were permitted are also subject to greater than usual (but not much) congressional oversight. The Chief Justice's opinion for the Court, next to unanimous, upheld the statute on the basis of an analysis far less formalistic than that which had characterized the decisions in Chadha and Bowsher. I imagine that Professor Rubin would think, as I do, that on this occasion the Court produced a correspondingly more satisfying analysis.

What ought to be noted, however, is that the analysis was not one that gave up the game of distinguishing between President and Congress or that failed to recognize that some choices about political controls denied the President or reserved to the Congress produce constitutional difficulty. The analytic questions for the Court included such issues as whether the President's controls over special prosecutors, although diminished, remained sufficient to preserve (and avoid impermissible interference with) the characteristic functions of his (the President's) office; ${ }^{43}$ whether the controls Congress had reserved for itself were such as to exceed the characteristic functions of the legisla-

41. It is important to this line of reasoning to distinguish sharply between the President and the ordinary agencies of government, and note that, in the arena of domestic regulation at least, the functions of the presidency also have become intransitive. His is an office that guides, shapes, and controls; but decision and implementation, as with Congress, are placed in the agencies themselves, not in his hands. See Strauss, The Place of Agencies in Government: Separation of Powers and the Fourth Branch, 84 Colum. L. Rev. 573, 587-95 (1984); supra note 40

42. 108 S. Ct. 2597 (1988).

43. Id. at 2621-22. 
ture; ${ }^{44}$ and whether the result as a whole reflected an attempt by Congress to increase its own powers at the expense of the Executive Branch. ${ }^{45}$ That Congress might exercise political controls and attempt to separate administration from executive politics to some extent was not denied; but such political controls as Congress might exercise had to be assessed in the context of a continuing distinction between executive and legislative activity, and in light of their impact on the President's characteristic role.

The presidency is missing from Professor Rubin's paper, and its absence saps the force of the prescriptive analysis. A theory of legislation addressed to the problems of intransitivity ought to recognize the existence and role of the President as our most powerful political actor, both entitled to exercise his own characteristic oversight roles and protected from undue interference in those roles (or confusion about who is playing them). Granted that intransitivity gives added dimension to the problem of continuing political control, reasons of both constitutional and practical dimension may suggest placing some such controls in the President's hands rather than the Congress's, or counsel at least that some rough parity, some principle of nonexclusion, be observed between them. That the President will be playing suggests, too, an additional element to the congressional dynamic-especially in these times of split political responsibility for government; in creating an intransitive regime, Congress delivers substantial control to the President and thus raises for itself the problem how it can disarm the lobbyists who may be successful over there in defeating its own policy preferences. ${ }^{46}$

\section{A Reassessment of Some Elements of the Critique}

Professor Rubin's observation that the delegation and void-forvagueness doctrines are rather beside the point as constraints for a Congress producing intransitive legislation provides useful insight. While one could cavil with the argument in some respects, ${ }^{47}$ its conclusions are persuasive. It does not follow, however, that these ideas are without continuing utility in the present era. Consideration of how

44. Id. at $2620-21$.

45. Id.

46. See, e.g., text following supra note 20 .

47. Thus, the discussion at the theoretical level becomes more difficult once one acknowledges that Congress is not the source of legislative authority but its recipientthat the original "delegation" of legislative authority occurs in the Constitution, from the people to Congress. Drawing on the very understandings about general agency law that Professor Rubin cites, supra note 10, at 389 n.66, John Locke argued, influentially so far as the drafters of the Constitution were concerned, that such grants from the people of legislative power were ones "only to make laws, and not to make legislators." J. Locke, Second Treatise on Civil Government $§ 141$. That principle is, nonetheless, one that "has fallen before the inexorable momentum of the administrative state." Monaghan, Marbury and the Administrative State, 83 Colum. L. Rev. 1, 25 (1983). 
these doctrines might operate as part of the necessary network of political and legal controls constraining agency activity might have suggested that the ideas remain vital and helpful.

Regarding delegation, it may be useful to start with Professor Rubin's observations that "the passage of legislation and the consequent authorization of a federal implementation mechanism is not only an initial exercise of legislative power, but a framework in which that power continues to be exercised," 48 , and that as a matter of general constitutional principle, "all organs of government should be constrained by rules, and . . . their obedience to those rules should be supervised by some formal or informal method." 49 These observations, powerful as they are, open a series of questions to which the idea of delegation has some relevance. They suggest that the quality of even an intransitive statute as "framework" has significance, and that it would be appropriate to focus attention on the behavior of the agency as delegate to determine what does, and does not, serve to constrain. Taken in conjunction, they suggest the appropriateness of considering also the impact on Congress-an organ of government- of various constraints on its behavior during the post-statutory period during which "power continues to be exercised."

Thus, a different way to assess the failures or successes of the delegation doctrine might be to look at the behavior of government agencies in formulating and defending their work-product. Thousands of government attorneys spend much of their time demonstrating in internal memoranda, and when relevant in opinions, rulemakings, and judicial briefs, the bases on which proposed official action can be thought authorized (or not) by governing statutes. While these conclusions may be given dispositive weight when statutes are acknowledged themselves to provide no sharp resolution of the question raised, ${ }^{50}$ the structure of the argument, the behavior of formal justification, is itself important. Government attorneys do not think it relevant ("safe" is perhaps a better term) to argue that, since a statute was imprecise or broadly worded, the agency may do anything it pleases, or that a court or other outside observer cannot competently tell whether it is or is not acting within authority. They acknowledge the obligation to demonstrate authority-and with it, all the other issues about regularity that follow, such as consistency with (or an explanation of departure from) prior results, procedural correctness and the appropriate exercise of judgment.

The delegation doctrine thus provides the impetus for agency concessions that the exercise of certain forms of discretion is subject to review for "abuse." Even if we must acknowledge at the outset that the

48. Rubin, supra note 10 , at 392 .

49. Id. at 392 n.75. (1984).

50. Chevron U.S.A. v. Natural Resource Defense Council, 467 U.S. 837, 842-45 
agency will often succeed in justifying its conduct, precisely because the statutory formula is diffuse (very often deliberately) and agency discretion correspondingly large, the stance won-that the agency must be prepared to justify its behavior to outside assessors in accordance with principles of regularity and legality-is no trivial matter. ${ }^{51}$ The very fact of confidence in the possibility of supervision, and the winning of behavior from government that acknowledges its appropriateness and inevitability, lies at the heart of a commitment to the rule of law. This sense of delegation, which Professor Rubin identifies as constitutional in character, ${ }^{52}$ remains vital; that, it is not difficult to say, is what underlies the persistence of A.L.A. Schechter Poultry Corp. v. United States. ${ }^{53}$ The regularity and accessibility that a government must promise in order to remain "under law" were missing in that case; the government's behavior, ${ }^{54}$ Congress's generosity and the temper of the times conjoined to rob the Court of the assurance it must ultimately have that it would be able to say whether discretion conferred by law, but having to remain subject to check, had been abused.

One might then ask whether this rule of law idea of delegation, diffuse and difficult as it may be, provides any appropriate constraints over Congress. Direct control over the necessary specificity of legislative action is not the only possibility in this regard. One can imagine, also, constraints whose tendency might be thought to induce Congress to make as many choices in advance as reasonably possible, or to reduce the chance of undesirable (because private, or distorting of public agendas, or the like) "controls" exercised after initial establishment of the legislative framework. To acknowledge that statutes may be intransitive, providing a framework for continuing interaction rather than a present resolution of policy issues, ought to heighten concern over just what the postenactment behaviors of members of Congress might be and how the possibility of their continuing control might feed back on

51. For this reason, Professor Rubin appears to move too quickly from the proposition that courts no longer enjoy full interpretive control over statutory content, emphasized by the decision in Chevron, see supra note 36 and accompanying text, to the conclusion that they are "out of the loop." Rubin, supra note 10 , at 396 . The remaining judicial functions of boundary definition and regularity assurance, which he fairly identifies, are significant and important ones; the governmental behaviors that facilitate their exercise, as already suggested, seem the direct product of the "rule of law" aspect of delegation.

52. Rubin, supra note 10 , at 392 n.75.

53. 295 U.S. 495, 542 (1935) (striking down code-making provisions of the National Industrial Recovery Act as an "unconstitutional delegation of legislative power").

54. Compare Panama Ref. Co. v. Ryan, 293 U.S. 388 (1935), the other New Deal delegation case, in which the government was compelled to acknowledge at oral argument that the standard at issue not only was never published, but, through a drafting error, had in fact been vitiated-although it had still been relied on in the case. See Jaffe, An Essay on Delegation of Legislative Power, 47 Colum. L. Rev. 561, 571 (1947); Stern, The Commerce Clause and the National Economy, 1933-1946, 59 Harv. L. Rev. $645,658-60$ (1946). 
the legislative process or disturb our general hopes for regularity in government.

While Professor Rubin writes warmly of congressional oversight, he does not yet seem to have addressed himself concertedly to these issues. He limits the normative aspect of delegation as a "continuing constraint on the legislature itself" 55 to its (outmoded) push toward transitive legislative outcomes. He does not consider its tendency to enforce the general allocations of responsibility suggested by separation-of-powers theory, to enhance openness in the exercise of governmental authority, or to control the supplanting of formal congressional action by the "fraction which may be a faction." 56 Will oversight occur as the result of efforts of individuals or strategically placed small groups? It is then hard to ascribe to that oversight the political qualities of action by the legislature itself; the observation that "the legislature may be better able to control an administrative agency than to control itself" 57 is, in this respect, dangerously anthropomorphic. Moreover, the easier it becomes for Congress, or persons in some sense acting for it, to control agency behavior by other-than-legislative means, the less incentive there is to precision in initial drafting. Even conceding, as one must, that substantial intransitivity is inescapable in the modern context, one may regard with suspicion approaches that promise diminished congressional attention to its primary, public, legislative function in favor of other functions likely to prove both less public and less responsible. The public-choice literature Professor Rubin briefly discusses underscores these concerns, which will perhaps become more accessible below where they are addressed in the specific context of the legislative veto. ${ }^{58}$

Similarly, one wishes Professor Rubin had looked beyond direct application of the void-for-vagueness doctrine to statutes, to the possibility of systemic application. He convincingly shows us that for intransitive statutes in themselves, the void-for-vagueness idea (which he takes to represent Professor Lon Fuller's principles of morality in law) has little utility. But Fuller formulated his principles, as Professor Rubin recognizes, for "a system for subjecting human conduct to the governance of rules," 59 and that suggests that their utility is not to be assessed by looking at the legislative output alone. Professor Rubin's assertion that "[w]hen [a] statute is enforced by an agency, our normative system simply does not make the demands that Fuller perceives" 60 is correct only with regard to the statute as subject, not with regard to the broader system of which it is a part.

55. Rubin, supra note 10 , at 393 .

56. See MacMahon, supra note 20, at 414 .

57. Rubin, supra note 10 , at 394 .

58. See infra notes $68-72$ and accompanying text.

59. Rubin, supra note 10 , at 398 (emphasis added).

60 . Id. at 399 . 
Thus, vagueness or a lack of clarity in modern legislation is tolerated because it exists within a system that does give legal obligations or restrictions more precise shape before the citizen is asked to act or subjected to penalties for unwanted behavior. The agency's development and enunciation of administrative policy serves, in this respect, precisely the same function as does a judicial "narrowing construction" in conventional void-for-vagueness jurisprudence; it provides the requisite clarity and assurance of acceptable stability in results. Seen as an obligation applicable to the system, embracing agency and Congress together, the other elements of Fuller's analysis seem equally apt. In using the term "law," he was not limiting himself to statutes; while it is apt to say that he probably did not have the world of public administration in mind, he sought to describe the morality of a system, not its particular elements. What Professor Rubin has done, then, is to indicate that the statute in isolation is not the appropriate focus of the Fuller analysis; but he has not shown that analysis to be inappropriate for the system as a whole.

Again, in formulating a theory of legislation that accepts as a starting point the appropriateness of substantial intransitivity by the originating legislature, what one hopes to see is an account that considers the functioning of the system as a whole-that considers how particular approaches to the possible styles and varieties of legislative action (here including postenactment oversight in all its forms) are likely to contribute to or detract from both Congress's general performance of function in the constitutional framework we have and the acceptability of that system's output as "law." To the extent Professor Rubin's purpose is descriptive, to show that our present tools for controlling legislative behavior are inadequate to our present needs for legislation, he has succeeded wonderfully, and the forgoing ought not be taken as doubting that in the least. But he seems also to be thinking about how things ought to be-what a replacement theory of legislation should look like-and here it seems to me that he and others building on his work must carry through on his insight. Precisely because the new legislation is intransitive and interactive, a new theory of legislation must consider Congress and its functioning in systemic context. How and with what resources it operates needs to be realistically considered, as must its relations with all the other actors of government. What controls it is as important an inquiry as how it might control others.

\section{An Example: The Legislative Veto}

The example of the legislative veto illustrates all three themes of these comments-the implications of Congress's bigness, the necessary issues of presidential role, and the possibility that some aspects of delegation and void-for-vagueness will remain useful in an intransitive era. Professor Rubin is persuasive that the formalist critique of the legisla- 
tive veto, based on presuppositions of transitive legislative action, is weak. We should accept, also, his proposition that "one important norm for the modern legislative process is that the legislature exercise political control over administrative agencies." 61 The legislative veto is one example of such a control-one that, indeed, he appears to favor. Suppose we were to view the legislative veto, however, through a lens accepting of the need for continuing political controls but concerned nonetheless with the issues that have been raised: relationship to the presidency; visibility and tendency to faction; and forward impact on the functioning of Congress generally. Would we conclude that a modernist theory of legislation should entail the legislative veto, in one or more of its several forms?

At the outset, we ought to define just which "legislative veto" we are addressing. Historically, it came in many forms and was employed in a variety of contexts, and the analysis suggested could vary among them. Take two examples: A provision that independent regulatory commission rules do not take effect if, within thirty legislative days of their promulgation either branch of Congress has adopted a resolution of disapproval; and a provision authorizing the President to reallocate appropriated funds to a project otherwise prohibited by a budgetary restriction if the relevant subcommittee does not object. The first of these provisions is quite formal, requiring the whole of a chamber to act in the public forum and reducing to that extent concerns about faction and responsibility; the action affected by the veto directly affects the public; the President is at least arguably excluded from the oversight process, suggesting possible separation-of-powers concerns; a veto, if exercised, will likely shape future agency action in other proceedings, without having changed any statutory provision; the very prospect of a veto may chill agency action by increasing agency-staff interactions; ${ }^{62}$ and the possibility of reserving a veto may influence how diligently future Congresses perform their legislative function. The latter of these provisions is informal, reflecting a process that is likely to occur in private and that will be influenced by only a few members; yet the public is not directly affected; the President is a direct participant in any dealings with the subcommittee and must concur for the change to take place; and it is hard to imagine how a subcommittee's reserved authority to permit reallocation would shape future behavior, detract from presidential authority or discourage future congressional diligence. ${ }^{63}$ The paragraphs following focus on the first form of legislative

61. Id. at 408 .

62. See supra text accompanying note 26 .

63. Appropriations are annual statutes, considerably more transitory than ordinary statutes, but nonetheless binding on the executive. Their annual nature gives them, from the beginning, more of a negotiated character. The form of restriction under discussion ("The Secretary may spend none of the funds hereby appropriated on [a described project] unless ...") reflects an initial stance of disapproval of the President's 
veto, although they include occasional comparisons with the second.

Such a veto was involved in Consumer Energy Council of America v. Federal Energy Regulatory Commission, ${ }^{64}$ one of two D.C. Circuit opinions finding legislative veto provisions unconstitutional that were summarily affirmed by the Supreme Court the week following its Chadha decision. At issue was the House of Representatives' legislative veto of a rule adopted by the Federal Energy Regulatory Commission (FERC)under the "incremental pricing" provisions of the Natural Gas Policy Act of 1978 (NGPA). ${ }^{65}$ The NGPA had been enacted with difficulty during the Carter Administration, with the closest controversy resolved in the House (which eventually adopted the veto resolution) by only a single vote. The controversy arose in substantial part, it appeared, because of doubts about the incremental pricing policy (and the general deregulation of natural gas prices it represented). A legislative veto over certain incremental pricing rules was seen as one of the elements necessary to persuade a reluctant Congress to enact the bill. When FERC adopted an incremental pricing rule in 1979 and sent it to Congress for possible legislative veto, the debates revealed little doubt about whether the agency had acted within its intended discretion under the Act; the sentiments predominantly expressed were that the Act itself had been a mistake, and so its implementation ought to be blocked by a legislative veto. ${ }^{66}$ Unlike the NGPA, the resolution permitted only a vote for or against; it embodied no text to be debated, possibly amended, and put into effect.

Running through the court's reasoning in disapproving the legislative veto in this case was a theme of relationship to the question of delegation. Legislative vetoes that had been accepted by the Executive even reluctantly-over reorganization acts, in the context of foreign affairs-had two characteristics, the court observed: they emphasized the

program that could otherwise be lifted only by statute. Deciding to permit the lifting of such restrictions informally, it could be argued, enhances the overall flexibility of the budgetary/appropriations process and weakens neither the President nor the Congress. See Strauss, Was There A Baby in the Bath Water? A Comment on the Supreme Court's Legislative Veto Decision, 1983 Duke L.J. 789, 812-17. Strikingly, legislative veto provisions of this character are still frequently enacted. Louis Fisher in an April 1987 report for the Congressional Research Service, "Legislative Vetoes Enacted After Chadha," counted 102 legislative vetoes enacted after Chadha, virtually all of this type.

The appropriations context is, perhaps relatedly, one of extraordinary reliance on legislative history enforced by politics. Appropriations statutes most often do not specify detailed spending directives; these directives appear in the committee reports. While it has asserted its formal independence from these prescriptions, the White House has generally gone along. Miller Acts to End Feud With Hill Over Funding, The Washington Post, July 12, 1988, at A21, col. 1 .

64. 673 F.2d 425 (D.C. Cir. 1982), aff'd sub nom. Process Gas Consumers Group v. Consumer Energy Council of Am., 463 U.S. 1216 (1983).

65. Pub. L. No. 95-621, 92 Stat. 3351 (1978) (current version at 15 U.S.C. $\S \S 3301-3342$ (1982 \& Supp. IV 1986)).

66. 673 F.2d at $468-69$. 
standardlessness of the original legislation, and they occurred in constitutional contexts in which such standardlessness might be of lesser concern. Government reorganizations do not directly affect private persons; the President and Congress share the foreign affairs function in complex ways; use of the veto device promotes flexibility without threatening either executive or legislative function. The rulemaking authority delegated to FERC, on the other hand, was authority directly to govern the affairs of private individuals. To be valid, even under the weak form in which "delegation" still survives, a statute had to promise an administrative process that assured rulishness, against which the conformity of agency action could be assessed. In effect, the courts had to be in a position to assure themselves that however diffusely Congress may have defined a reservation, there was a reservation off which the agency was not to stray and the courts would be in a position to say on the basis of reasoned analysis whether or not an agency had wandered. "Arguments that Congress actually decided nothing whatsoever about .. . incremental pricing" would raise "serious" delegation questions. ${ }^{67}$ But the tendency of permitting a legislative veto would be precisely to permit Congress to decide "nothing whatsoever;" the need to articulate standards would be all the less if, once an agency had attempted to act, Congress had free and unreasoned opportunities to vote approval or disapproval of the choices the agency had made.

This way of viewing the transaction also highlighted for the court the manner in which the veto would work to undercut the general purpose of the Constitution's framers to make "the legislative power . . . difficult to employ" 68 and their specific purpose to assure the President an important role in the process. Congress might be encouraged to use the legislative veto, not only because it makes its work easier (members would then not have to work so hard to come to resolution as they would on standards to be applied finally, with full legal effect, by others), but also because it saps the President's veto. He might try to block the initial decision of "nothing whatsoever," but if that failed he would have no control over Congress's choice whether or not to block agency action when the agency subsequently adopted a policy. Here is a technique that, if permitted, could destroy the constitutional veto. This impact was underscored by the consideration that the agency involved in the particular case, FERC, was an independent regulatory commission, generally understood to be rather more removed from presidential oversight and control than run-of-the-mill executive agencies. 69 "The fundamental justification for making agencies independent is that . . political interference is undesirable. By then turning around and asserting that this independence is a justification for the one-house veto, Congress attempts simultaneously to decrease the

67. Id. at 467.

68. Id. at 464 .

69. Id. at $470-479$. 
power of the Executive and increase its own power."70

Finally, the court looked explicitly at the issue of congressional oversight.

When Congress conducts investigations or hearings, or enacts a "report and wait" requirement, or threatens to reduce appropriations, or imposes reporting requirements, or engages in other modes of oversight, its ability to influence the agency derives almost entirely from its ability to pass a statute requiring a different agency action or reducing the agency's appropriations. These oversight methods enable Congress to inquire "into past executive branch action in order to influence future executive branch performance." [Under the legislative veto,] Congress is able to expand its role from one of oversight, with an eye to legislative revision, to one of shared administration. ${ }^{71}$

And, the court went on to note, it ought not be easily assumed that Congress's power would be limited to the chamber acting. "The onehouse veto also increases sharply the negotiating power of individual congressmen or committees in seeking to direct administrative outcomes."72 That judgment is easily accepted and entails factional politics that are both uncontrolled (because likely private) and severe.

This last point, that legislative vetoes would enhance committee power, suggests a connection to the problem of congressional size that warrants equal concern. Here might be an impetus to further enlargement of the already swollen congressional bureaucracy. To be sure, one might argue that legislative vetoes, if available, would displace (by reducing the necessity for) other, more covert forms of oversight. Yet in my judgment, particularly in the present context of Republican-Democrat struggles for control of the agencies from the White House and Capitol Hill, the threat of a possible veto would arm more, not less, covert activity. Political responsibility for committee communications to the agencies would be at best problematic, with the problems being resolved (to the extent they could be) by supervisory efforts on the part of members of Congress that would necessarily subtract further from the time available to them for directly legislative work. Given the private, bureaucratic, and fractional (likely factional) nature of those communications, and the unexplained nature of any resulting veto, any idea that a legislative-veto regime would be constrained to the enforcement of pre-existing congressional intentions about statutory meaning is chimerical. It would be an arena for current politics.

Even if one grants, then, that it may be necessary to set one bureaucracy to catch another, that the size of government generally beggars its direct control by elected individuals, one still must ask why that

70. Id. at 472 .

71. Id. at 474 (footnotes omitted).

72. Id. at 475 n.213. 
watchdog bureaucracy should be distributed among the politically fractured Congress, rather than placed in the politically unified office of the President. ${ }^{73}$ Coherence remains a desirable end in government, whether Congress can supply it directly or must leave its working out to others. The case that the 535 members of Congress, with their army of more than twenty thousand bureaucrats, can supply that coherence by oversight remains to be made.

Finally, consider what Professor Fuller's analysis might suggest about whether a legislative-administrative system should include the legislative veto. Professor Rubin recognizes that that analysis may have a good deal more to say to us about the desirable qualities of a system of law than about the desirable qualities of statutes as such, and with that judgment it is hard to disagree. He suggests that in general the system of intransitive statutes supplemented by rules does meet Fuller's demands; one might add that that system without the legislative vetothat is to say, with the agency having authority to act pursuant to its mandate, subject only to ordinary political and judicial controls-provides incentives for Congress to state the agency's authority, to the extent possible, in ways that also support them. How would adding the veto change matters? One could believe that it would impair "generality" in two respects: by diminishing the need for initial standard-setting, it would reduce the rulishness of the initial legislative output; and the arbitrary and unexplained character of legislative vetoes when exercised would frustrate any description of the overall system as operating in terms of general rules. "Promulgation," making the law "readily available," is similarly impaired: Congress has less reason to write statutes initially in a way that will make them accessible to the public; it is, to that extent, able to operate in secret, without either revealing its policy choices or being bound to treat agency choices made under delegation in any coherent way. While delegation to agencies provides, overall, a defensible means both for avoiding contradiction and impossibility and for securing constancy and congruence, the veto would undercut these qualities as well.

Is this the Congress we want-one with diminished incentives to reach whatever judgments might be possible on legislative issues, fewer reasons to accommodate the President, enhanced capacities to disrupt administration, and diminished political responsibility for the controls those associated with it may exercise over government? Few would disagree with Professor Rubin that we must accept the intransitivity of contemporary legislative action and seek a theory of legislation that will acknowledge it. Congressional scholars have no difficulty in finding institutional incentives pointing strongly in the direction of individual or small-group casework, rather than the elusive business of coalition-

73. See, e.g., National Academy of Pub. Admin., supra note 40, at 23 (more appropriate congressional role is oversight of $\mathrm{OMB}$ ). 
building, as the preferred congressional task. ${ }^{74}$ The formulation of a new theory might include, as one of its tasks, the possibility of institutional structures or demands that would push back toward collective action. My concern is that, in pursuing that task, we do not abandon an interest in having Congress function as a legislature, in preserving the place of the President and (more broadly) what remains vital about our notions of separation of powers, or in accommodating the impact of bureaucraticization in government generally in ways that do not compound its problems.

\section{ConClusion}

Rubin succeeds in persuading us that the traditional equation of "legislation" and "law" is problematic in the administrative state-that legislation is more often concerned with the (other) organs of government from which "law" emerges than with its direct formulation. Yet even if we accept this as a natural development, not a disease of which the body politic should be purged, the relationships between those responsible for "legislation" and those responsible for "law" should be a matter of active concern. Our wish for law, for conditions that will conduce to its creation, remains relevant to any theories we may hold for legislation. If delegation and void-for-vagueness, for example, do not serve well as direct measures of the worth or validity of legislative products, they continue to embody systemic values deserving of respect and consequently influencing our notions of appropriate relations between the legislative and law making efforts to the extent those are distinct. An insight that properly turns our attention from performance to control needs to notice how various options on the placement or exercise of control may affect the law-character of the system's ultimate output. Congress is not the only institution controlling, and the new theory for which Rubin calls must be concerned both with separation-of-powers questions concerning the appropriate allocation of controls across the whole of government, and the probable impact on Congress's legislating of the various kinds of controls that might be imagined. While today's theory of legislation must be differentiated from our theory of law, one cannot free one from the other. Professor Rubin's analysis pays insufficient heed to the continuing relationships.

74. R. Fenno, Home Style: House Members in Their Districts (1978). See generally the essays collected in Parts I and IV of Congress: Structure and Policy, supra note 1 . 